\title{
Jesuit Hebrew Studies After Trent: Cornelius a Lapide (1567-1637)
}

\author{
Luke Murray \\ Katholieke Universiteit Leuven / Ave Maria University \\ Postdoctoral Fellow of the Research Foundation - Flanders \\ luke.murray@kuleuven.be
}

\begin{abstract}
This essays studies the biblical hermeneutics of Cornelius a Lapide, focusing on his knowledge of Hebrew. After reviewing a post-Tridentine bias against Catholic biblical studies, the essay is divided in three parts. The first part is a brief introduction to a Lapide's life; the second part addresses his position on the Vulgate and its relationship to the original languages of scripture; and the third part presents key passages from a Lapide on the Hebrew language, drawn from his biblical commentaries. In the end, I argue that regardless of a Lapide's imperfect knowledge of Hebrew, he still shows that Catholic scholars could engage in a close study of scripture's original languages after Trent's decree on the Vulgate, and could incorporate works from across confessional boundaries.
\end{abstract}

\section{Keywords}

early modern Catholic exegesis - Cornelius a Lapide - Hebrew - biblical hermeneutics Vulgate - scripture - humanism - Jesuits - Trent

One figure who has been neglected in the study of early modern Catholic exegesis, and Jesuit Hebraism in particular, is Cornelius a Lapide. A Lapide is an interesting figure because, unlike other scholars who were immersed in humanistic studies, the famous Jesuit remained largely unscathed by accusations of heresy and was never censured by the magisterium during his long career. In his studies of scripture after Trent's "Decree concerning the Edition and Use of Sacred Books," a Lapide reveals that post-Tridentine Catholic scholars were not

(C) MURRAY, 2017 | DOI 10.1163/22141332-00401004

This is an open access article distributed under the terms of the Creative Commons Attribution-

Noncommercial 4.0 Unported (CC-BY-NC 4.0) License. http://creativecommons.org/licenses/by-nc/4,0/02:10:24AM 
mere slaves to the Vulgate, but instead attempted to incorporate humanistic studies into a hermeneutic of scripture that could remain faithful to tradition, the church fathers, and the magisterium. This contradicts the impression given by Louis B. Pascoe's 1966 article "The Council of Trent and Bible Study: Humanism and Scripture" that Catholic scholars after Trent abandoned their work in Hebrew and Greek, taking refuge in the Vulgate and Scholastic philosophy because the council had chosen not to enforce humanistic scriptural reforms. Pascoe's article provides an excellent timeline and summary of the fourth and fifth sessions of the council, which addressed the interpretation of scripture, but implies that humanistic studies of scripture, including the study of Hebrew, all but ended after Trent, vanquished by Domingo de Soto's (1494-156o) Scholasticism and the fear of Protestantism.

In the final analysis, the failure of the bishops to make the required institutional changes in the education of the clergy rendered the biblical movement at Trent ineffective. By the time the Council had finally decreed the establishment of seminaries in 1563 , humanism as a factor in theology had run its course; a renascent scholasticism dominated theological studies. What the role of the Word of God might have been in the postTridentine church had the new institutional changes been successfully combined with humanistic methodology is the realm of pure conjecture. ${ }^{1}$

While it is true that Trent issued a cautious and minimalist decree on scripture, there is now a growing recognition today that Catholics continued to incorporate humanistic studies in their biblical studies, despite an increase in censorship. $^{2}$ One such study is Pierre Gibert's helpful, though brief, work on Cornelius a Lapide, entitled "The Catholic Counterpart and Response to the Protestant Orthodoxy." Gibert touches on a Lapide's biblical hermeneutic and states that he was a "sort of transition" in the history of biblical scholarship:

1 Louis B. Pascoe, "The Council of Trent and Bible Study: Humanism and Scripture," Catholic Historical Review $5^{2}$ (1966): $18-38$, here 38 .

2 See my dissertation for more on this negative view of early modern Catholic exegesis and on a Lapide's life and hermeneutics: Luke Murray, "Jesuit Biblical Studies after Trent: Franciscus Toletus \& Cornelius a Lapide" (PhD diss., KU Leuven / Ave Maria University, 2016). See also Wim François, "Augustine and the Golden Age of Biblical Scholarship in Louvain (1550-1650)," in Shaping the Bible in the Reformation: Books, Scholars and Their Readers in the Sixteenth Century, ed. Bruce Gordon and Matthew McLean (Leiden: Brill, 2012), 235-89; Allan Jenkins and Patrick Preston, Biblical Scholarship and the Church: A Sixteenth-Century Crisis of Authority (Burlington, vT: Ashgate, 2007); Peter Godman, The Saint as Censor: Robert Bellarmine between Inquisition and Index (Leiden: Brill, 2000). 
How should one appreciate this sizeable work that marks a sort of transition between the humanist heritage of the sixteenth century, memories of the patristic and medieval tradition, and a predominant concern for the literal meaning, yet, which is pre-critical compared to the demands of Simon and Spinoza? ${ }^{3}$

This essay is intended as a partial answer to both Pascoe and Gibert. In an effort to increase our understanding of early modern Catholic exegesis and, in particular Jesuit studies of Hebrew, this work will examine a Lapide's approach to scripture and his knowledge of Hebrew. This will be accomplished in three parts. The first part will be a brief introduction to the Jesuit's life, the second part will address his position on the Vulgate and its relationship to the original languages of scripture, and the third part will present key passages from a Lapide on the Hebrew language, drawn from his biblical commentaries. In the end, I will argue that regardless of a Lapide's imperfect knowledge of Hebrew, he still shows that Catholic scholars could engage in a close study of scripture's original languages after Trent's decrees and could incorporate works from across confessional boundaries.

\section{Cornelius a Lapide}

Born at Bocholt in what is now Flemish Limburg on December 18, 1567, Cornelius a Lapide (Cornelis Cornelissen van den Steen) studied humanities and philosophy at the Jesuit colleges of Maastricht and Cologne, spent half a year studying theology at the University of Douai, and then studied theology for four more years at Leuven. In 1592, at the age of twenty-five, he entered the Society of Jesus and, after two years of novitiate and another year of theology, was ordained a priest in 1595. After teaching philosophy for half a year, he was made professor of scripture at Leuven in 1596 and professor of Hebrew the following year. In 1616, called to Rome by his Jesuit superiors, he taught scripture and Hebrew until later in life when he dedicated himself to writing his famous biblical commentaries. He died quietly in $1637^{4}$

3 Pierre Gibert, "The Catholic Counterpart and Response to the Protestant Orthodoxy," in $\mathrm{He}$ brew Bible / Old Testament, ed. Magne Saebo (Gottingen: Vandenhoeck of Ruprecht, 2008), 2:758-73. For a Lapide, see 2:764-67, here 765 .

4 Cf. Murray, "Jesuit Biblical Studies after Trent," 79-81. See also John P. van Kasteren, "Cornelius Cornelii a Lapide," in The Catholic Encyclopedia, 15 vols. (New York: Robert Appleton Company, 1907-12), 4:377. 
Cornelius a Lapide was a prolific commentator on scripture, writing on almost every book of the Bible. ${ }^{5}$ He was also interested in inter-confessional dialogue and the relationship between scripture, philosophy, and emerging sciences. ${ }^{6}$ Affirming a distinction between the "book of nature" and the "book of scripture," a Lapide devoted himself to seeking the "harmonization between the contributions of the new approach to the universe [...] with the realities of faith, especially the teachings of the Bible." ${ }^{7}$ While he never doubted the authority of scripture as the word of God, he remained open to integrating the advances of the nascent modern sciences, and perhaps, even, the philosophy of Descartes. ${ }^{8}$ Since a Lapide held that God was the author of both nature and revelation, he affirmed that philosophy and physics could not contradict

5 Due to the lack of a critical edition, I consulted first editions but will primarily draw on the most recent 1891 edition of a Lapide's work: Commentaria in scripturam sacram, 26 vols., ed. Augustinus Crampon and Joseph-Maxence Peronne (Paris: Vives, 1859-63). I am using the latest edition that was printed in 1891 [hereafter Css]. All translations are my own unless stated otherwise. For other editions of a Lapide's work, including archive material, see Raymund Noll, Die mariologischen Grundlinien im exegetischen Werk des Cornelius a Lapide, 1567-1637 (Regensburg: Verlag Friedrich Pustet, 2003), 285-86.

6 On the Jesuit order in Leuven during a Lapide's time, see Jan Roegiers, “Awkward Neighbours: The Leuven Faculty of Theology and the Jesuits [sic] College (1542-1773)," in The Jesuits of the Low Countries: Identity and Impact (1540-1773), ed. Rob Faesen and Leo Kenis (Leuven: Peeters, 2012), 153-75; William Bangert, A History of the Society of Jesus (St. Louis, MO: Institute of Jesuit Sources, 1972); László Polgár, Bibliographie sur l'histoire de la Compagnie de Jesus, 5 vols. (Rome: Institutum Historicum Societatis Jesu, 1981); Carlos Sommervogel, Bibliothèque de la Compagnie de Jésus (Paris-Brussels: Picard-Schepens, 1890-1932), 4:1511-26; Alfred Poncelet, Histoire de la Compagnie de Jésus dans les anciens Pays-Bas (Brussels: Marcel Hayez, 1927); Martin P. Harney, The Jesuits in History: The Society of Jesus Through Four Centuries (Chicago: Loyola University Press, 1962); John W. O'Malley, The First Jesuits (Cambridge, MA: Harvard University Press, 1993). Paquot remarks that in 1608 a Lapide and his colleague, Adrian Mangot, took part in conferences held in Antwerp. There, the two Jesuits met with the two ministers from Rotterdam, François Landsberghen and his son Samuel. The outcome of this dispute is unclear. See Jean Noël Abbè Paquot, Mémoires pour servir à l'histoire littéraire des dix-sept provinces des Pays-Bas, de la principauté de Liège, et de quelques contrées voisines, Louvain, 1763-1770 (Louvain: L'Imprimerie Academique, 1766), 7:336.

Gibert, "Catholic Counterpart," 766.

8 Ibid. See also Vincent Carraud, "Descartes et la Bible," in Le Grand Siècle et la Bible, ed. JeanRobert Armogathe (Paris: Beauchesne, 1989), 277-91, here 277. For more on Jesuit philosophy during the late sixteenth and seventeenth centuries, see Emanuel J. Bauer, "Francisco Suárez (1548-1617): Scholasticism after Humanism," in Philosophers of the Renaissance, ed. Paul Blum, trans. Brian McNeil (Washington, DC: Catholic University of America Press, 2010), $236-55$. 
revelation because "[God] is the source of all that is number, order and mode of nature." Of course, a Lapide did remark that "holy scripture itself should not be twisted to adapt to the opinions of philosophers, or [to] the light and dictatorship of [the science] of nature." ${ }^{\prime 9}$ While a Lapide held to the authority of scripture and was thoroughly familiar with the church fathers (especially Augustine), he was also acquainted with the works of his contemporaries. ${ }^{10}$ Indeed, he lamented that the explosion of biblical commentaries made it difficult for a scholar just to read, let alone judge and engage with, the commentaries of his day. ${ }^{11}$ The contemporaries which he cites most frequently include Alfonso Tostado (1400-55), Santes Pagnino (1470-1541), François Vatable (c.1495-1547), Andreas Masius (1514-73), Cornelius Jansen "The Elder" (1510-76), Alfonso Salmerón (1515-85), Juan Maldonado (1533-83), Francisco de Toledo (1532-96), Guy Lefèvre de la Boderie, (1541-98), Francis Lucas "of Bruges" (1548-1619), Sebastião Barradas (1543-1615), and Desiderius Erasmus (1466-1536). He also noted that the "heretics," Martin Luther (1483-1546), John Calvin (1509-64), Huldrych Zwingli (1484-1531), Martin Bucer (1491-1551), Wolfgang Musculus (1497-1563), Heinrich Bullinger (1504-75), Johannes Brenz (1499-1570), and Theodore Beza (1519-1605) had commentated on the gospels, although his knowledge of their works seems to have been largely mediated by the Symmystes, a catena or anthology of those commentaries compiled by Augustin Marlorat (1506-62). ${ }^{12}$ Although a Lapide extensively studied the works of both the church fathers and his own contemporaries, this study did not detract from, but rather informed his own scholarly work.

9 Gibert, "The Catholic Counterpart," 766.

10 Cf. Murray, "Jesuit Biblical Studies after Trent," 110-16. As Matthew Levering points out, anyone familiar with a Lapide's commentaries soon notices "something of an encyclopedic character" to his knowledge of the fathers. Matthew Levering, Participatory Biblical Exegesis: A Theology of Biblical Interpretation (Notre Dame: University of Notre Dame Press, 2008), 195. See also Michael Cahill, "The History of Exegesis and Our Theological Future," Theological Studies 61 (200o): 332-47; Joseph Crehan, S.J. "The Bible in the Roman Catholic Church from Trent to the Present Day," in The Cambridge History of the Bible, vol. 3: The West from the Reformation to the Present Day, ed. Stanley Lawrence Greenslade (Cambridge: Cambridge University Press, 1963), 199-237, here 217.

11 A number of a Lapide's New Testament works, including his Gospel commentaries, have been translated into English; see Cornelius a Lapide, The Great Commentary of Cornelius a Lapide, 8 vols., trans. Thomas Mossman and William Frederick Cobb (London- Edinburgh: John Hodges-John Grant, 1887-1908), here 1:xxxi.

12 A Lapide mentions in his introduction to the Pentateuch that among so many different scholarly opinions, he "will select and offer those interpretations that are in the most harmony with the text." css, 1:15-16. 


\section{A Lapide on the Original Languages of Scripture}

As a faithful Jesuit, a Lapide was surely aware of Diego Laínez's (1502-65) guidelines for exegesis and the directive to base one's interpretation on the literal sense as confirmed by the church. ${ }^{13}$ Yet determining how exactly a Lapide understood the relationship between the Vulgate and the original languages requires a close examination of his commentaries. As we will see, he did not simply view the Hebrew and Greek texts as extra, gratuitous aids for understanding the Vulgate, as if the Vulgate was the only thing one needed for studying scripture. Rather, he viewed the original languages as the fonts from which flowed divine truth and which had to be mastered to come to the genuine sensus of scripture.

A Lapide was aware of Trent's decrees and considered them to be authoritative. Among his comments regarding councils in general, he states that the pope must always be present (in person or through his legates) for a general council to be authoritative, that an ecumenical council which represents the entire church cannot err, and that general councils are guided by the Holy Spirit. ${ }^{14}$ Regarding Trent itself, a Lapide shows his awareness of the important issue of episcopal residency by citing the council's decree regarding the funding of poor dioceses in his commentary on the wicked priests of Ezechiel 34:3. ${ }^{15}$ Concerning the Vulgate, he states that it is from antiquity that Jerome $(c .347-420)$ was the author of most but not all of it, that its faithfulness has been approved and defended, and that it should be considered authentic scripture. ${ }^{16}$ Thus far, a Lapide seems to validate Jared Wicks's contention that the Jesuits studied the original languages in order to defend the Vulgate. ${ }^{17}$ To be sure, he believed that the sensus of the Vulgate could not be in error since Trent had confirmed that it was authentic and true scripture. In his commentary on Sirach 44:16, where the Vulgate adds that Enoch was "transported into paradise" (a phrase absent in the Septuagint), he explains that it is de fide that Enoch was transported into heaven and that Trent has confirmed that the Vulgate should "be preferred to the Greek and Hebrew."18

\footnotetext{
13 "Documenta ad bene interpretandas scripturas," in Disputationes Tridentinae, 2 vols., ed. Hartmann Grisar (Innsbruck: Rauch, 1886), 2:501-5.

14 See, respectively: css, 18:527; 19:16o; 15:596; 14:412.

15 CSS, 12:742.

16 See, respectively, CSs, 10:308; 9:22; 6:311; 3:262, 610; 10:16.

17 Jared Wicks, "Catholic Old Testament Interpretation in the Reformation and Early Confessional Eras," in Hebrew Bible / Old Testament, 2:617-48, here 636-39. For more on the Jesuit order's position on the Vulgate and original languages of scripture, see Murray, "Jesuit Biblical Studies after Trent," 27-33. 
However, lest one think a Lapide lacked an appreciation for the original texts and languages of scripture and gave blind faith to the Vulgate, he admits that the Latin text has been edited, that it is not easy to reconcile with the Septuagint in many places, and that it is "not entirely pure."19 While he respected the Vulgate on account of its affirmation by Trent, he held a particularly high view of the value of the original languages, as evidenced by his comments introducing his reader to the book of Ecclesiasticus:

Here, the Latin translator often uses Greek phrases. He was likely a Greek who was not an expert in Latin. Therefore, the force of the Greek voice, as well as the Hebrew (if one is permitted to search and conjecture it from other places in scripture; for the Hebrew of Ecclesiasticus does not exist) should be carefully investigated and examined. Hence we learn how useful the knowledge of the Greek and Hebrew languages are, and the difference it makes when the Hebrew and Greek fonts of scripture are examined; for it is from [the Hebrew and Greek fonts of scripture] that the genuine sense and mind of sacred scripture are found and interpreted. ${ }^{20}$

While a Lapide does not explicitly say that it is absolutely necessary to examine the original languages of scripture (due to Trent's decree), he comes as close as possible by identifying the Greek and Hebrew texts as "the fonts" of scripture, in which are found the "genuine sense and mind of scripture."21 His reliance on Augustine here is obvious. When wading into the dangerous waters of promoting the original texts and languages of scripture, he almost always cites Augustine's De doctrina christiana:

Hebrew and Greek idioms, everywhere so common, make the difficulty much greater for those seeking to understand [scripture], and necessitate knowledge of both languages, as Augustine teaches in book II of $D e$ doctrina christiana. For the two reasons why the scriptures are not understood are when their sense is concealed by either unknown signs or ambiguous words. Both difficulties are common in every version which translates one idiom into another language. Again, for unknown signs, as Augustine says in chapters 11 and 13, a great remedy is the knowledge of languages. For there are certain words of one language which cannot pass into another through interpretation. Thus, the most learned interpreter

19 See, respectively, css, 12:818; 5:7, 126. See also Murray, "Jesuit Biblical Studies after Trent," $116-21$.

$20 \quad$ CSs, 9:39.

21 "genuina s. scripturae sensa mentemque," css, 9:39. 
is the one who does not deviate from the sense of the author when the meaning is not apparent and has to be inspected in its original language. ${ }^{22}$

A Lapide clearly affirms the usefulness of Hebrew and Greek for understanding scripture. It is because Hebrew and Greek have certain idioms and phrases that cannot be properly translated into another language that one must examine them to understand scripture's meaning, or, to "shed light" on the Vulgate. As we saw earlier, he believed that the sense or meaning of the Vulgate could not be in error since it was "authentic and true scripture," but he does not say that one can arrive at scripture's genuine sense and mind from the Vulgate; for this, the original texts and languages are needed. By the genuine sense, a Lapide appears to mean that while the Vulgate properly contains the true significance of scripture, only the original languages allow the deepest penetration into the mysteries of revelation and the meaning intended by the Holy Spirit. The original Hebrew and Greek therefore serve to "shed light" on the Vulgate by allowing one to come to a fuller understanding of the truth that the Vulgate conveys. ${ }^{23}$

In regard to a Lapide's actual knowledge of Hebrew, there are a number of places where he discusses the language in his commentaries. ${ }^{24}$ Examining these passages will show that he took great interest in the Hebrew language

22 CSS, 1:10-11.

23 CSS, 13:427. For more on a Lapide's biblical hermeneutic, see Murray, "Jesuit Biblical Studies after Trent," 81-125; Murray, “The Fall of Judas: Grace, Free Will, and Predestination in Early Modern Catholic Biblical Commentaries," Augustiniana 3, no. 4 (2015): 185-203; Henry Koren, "De inspiratione sacrae scripturae secundum doctrinam Cornelii a Lapide" (PhD diss., Catholic University of America, 1942); Romualdo Galdos, "De canonibus exegeticis apud P. Cornelium a Lapide," Verbum Domini 17 (1937): 146-52; Galdos, "De scripturisticis meritis Patris Cornelii a Lapide I," Verbum Domini 17 (1937): 39-44; Galdos, "De scripturisticis meritis Patris Cornelii a Lapide II," Verbum Domini 17 (1937): 88-96; Galdos, "Le troisieme centenaire de la mort du P. Cornelius a Lapide, S.J.," Nouvelle revue theologique 64 (1937): 1103-10; Sebastiano Pagano, "Analysis notionis inspirationis s. scripturae apud Cornelium a Lapide," Revue de l'Université d'Ottawa 15 (1945): 65-85; Jean-Pierre Delville, "La Lettre de Jacques aux XVIe-XVIIe siècles chez les exégètes catholiques en particulier Érasme, Guillaume Estius et Cornelius a Lapide," in L'épitre de Jacques dans sa tradition d'exégèse, ed. Annie Noblesse-Rocher, Gilbert Dahan, and Mathieu Arnold (Paris: Cerf, 2012), 119-45; Delville, L'Europe de l'exégèse au XVIe siècle: Interprétations de la parabole des ouvriers à la vigne, Matthieu 20, 1-16 (Leuven: Leuven University Press, 2004). For a recent study of a Lapide's mariology, see Raymund Noll, Die mariologischen Grundlinien im exegetischen Werk des Cornelius a Lapide (1567-1637) (Regensburg: Friedrich Pustet, 2003).

24 Helpful in navigating a Lapide's commentaries is the index put together by JosephMaxence Peronne, "Memoriale praedicatorum sive synopsis biblica, theologica, moralis, historica et oratorica commentariorum R.P. Cornelii a Lapide in scripturam sacram complectens omnium rerum quae in hisce commentariis enucleantur, " in css, vols. $25^{-26}$. 
and, despite his shortcomings, attained considerable skill. Attention to his comments on the Hebrew language provides some insight into the state of Catholic and Jesuit Hebrew studies in the late sixteenth and early seventeenth centuries. $^{25}$

\section{Cornelius a Lapide's Knowledge of Hebrew}

Before examining a Lapide's comments on the Hebrew language, one must first situate him within his historical context. The task is enormously difficult due to the neglected state of early modern Catholic Hebrew studies. As to his sources, a Lapide preferred current resources over traditional ones (i.e. Jerome) and used multiple Hebrew, Aramaic, and Syriac grammars. He certainly was aware of Robert Bellarmine's (1542-1621) Hebrew grammar, published in $1580 .{ }^{26}$ Quickly gaining fame within the Jesuit order and the church at large, Bellarmine's work was likely present when a Lapide was studying at the Jesuit colleges at Maastricht and Cologne. In addition, Bellarmine was also a professor at Leuven during a Lapide's tenure as the professor of Hebrew; he surely came to know him and his work on a personal level. Thus, it is not surprising that he frequently draws on Bellarmine's works and directly cites his Hebrew grammar in his commentary on Matthew 2:23. After summarizing and explaining that the two interpretative traditions regarding Jesus being called "a Nazarene" are related to reading the Hebrew with a zain or tsade (if with a zain, a Lapide says it means sanctified, separate or consecrated; if with a tsade it means full of flowers, a sprout, or coming from a root), he then proposes that the two positions may be reconciled and in the process cites the Hebrew commentaries "of Bellarmine and others":

Both opinions may be conjoined and reconciled with each other by saying that if you look strictly to the letters you will find nezer with

25 For a good overview of Christian Hebrew studies in the pre-modern period, see Aaron D. Rubin, "Christian Hebraists: Pre-Modern Period," in Encyclopedia of Hebrew Language and Linguistics, ed. Geoffrey Khan (Leiden: Brill, 2013), 1:449-52. For more on a Lapide's knowledge of Hebrew (discussed below), see Murray, "Jesuit Biblical Studies after Trent," $118-21$.

26 Robert Bellarmine, Institutiones linguae hebraicae (Rome: Franciscus Zanetus, 1580). On the Hebrew grammars in use in sixteenth-century Europe, see the excellent resource of Santiago García-Jalón de la Lama and Manuel Veiga Díaz, "Repertorio de gramáticas hebreas impresas en Europa en el siglo XVI," Helmantica: Revista de filología clásica y hebrea $5^{1}(2000): 535^{-742 .}$ 
zain - that is to say, holiness, consecration, crown; yet that there is an allusion to netser with tsade - i.e., a shoot, a flower - for these two letters are somewhat akin both in form and sound, and are occasionally interchanged both with one another and with some other Hebrew letters, as appears in the conjugation Hithpael. See Bellarmine's Hebrew grammar and others. Wherefore the psalmist conjoins the two (Ps. 132:18), saying: "My sanctification (nazer) shall flourish (nazarene) upon him." ${ }^{27}$

In addition to Bellarmine's grammar, the identity of the aliorum mentioned by a Lapide is more difficult to ascertain. However, it is clear that a Lapide had access to the Antwerp Polyglot Bible, since he often references "the King's Bible" and Benito Arias Montano (1527-98), its editor, in particular. ${ }^{28}$ Furthermore, he shows an awareness of the Grammatica syrochaldaica of Guy Lefèvre de la Boderie (1541-98) — found in an appendix to the Polyglot Bible-in his introduction to the Gospel of Mark. ${ }^{29}$ In addition to Lefèvre, a Lapide also cites Santes Pagnino (1470-1541) in his introduction to the Gospel of Mark and elsewhere. ${ }^{30}$ His familiarity with the Antwerp Polyglot Bible also means that he cites the Hebrew grammar of Plantin's son-in-law (found in appendix 7 of the Antwerp Polyglot), Frans van Ravelingen (1539-97), which was largely a compendium of Pagnino's earlier grammar. ${ }^{31}$ Andreas Masius (1514-73) and his Syriac grammar are also among the contemporary scholars a Lapide makes note of in his commentaries (also found in appendix 7). For example, in his comments on Galatians 3:13, a Lapide cites Masius to explain why the bodies

27 A Lapide, The Great Commentary, trans. Mossman, 1:94; A Lapide, Commentarii in IV Evangelia in duo volumina divisi: Tomus primus (Lyon: Jacob and Peter Prost, 1638), 80.

28 See a Lapide's introduction to the Gospel of Matthew in A Lapide, The Great Commentary, trans. Mossman, 1:xxix.

29 "The Syrians, as Fabricius tells us in the preface to his Syriac New Testament, assert that Mark wrote in Latin. They also say that the same Mark translated not only his own Gospel into his Galilean or Syriac mother tongue, but all the other books of the New Testament." A Lapide, The Great Commentary, trans. Mossman, 3:363. See also a Lapide's comments on 2 Cor. 4:10 for a reference to Lefèvre. A Lapide refers to Lefèvre's Syro-Chaldean dictionary/grammar in the Antwerp Polyglot. See Guidone Fabricio Boderiano, "Dictionarium Syro-Chaldaicum," in Biblia polyglotta Antwerpiae, vol. 7 .

30 For a Lapide's references to Pagnino, see his comments on his preface to Matthew's Gospel and also his comments on Mt 2:23; 12:29; 21:9; Lk 1:5; 2:17; 4:18; 8:2; Jn 11:1; 1 Cor 14:21.

31 Frans van Ravelingen, "Grammatica Hebraea: ex omnibus quibusque grammaticis collecta," in Biblia polyglotta Antwerpiae, vol. 7. Pagnino's Hebrew thesaurus is located at the very end of volume 7 . 
of dead criminals were to be taken down before the evening. ${ }^{32}$ A Lapide also appeals to the French humanist François Vatable $\left(c .1495^{-1547}\right)^{33}$ and was familiar with the works of Elias Levita (1469-1549) and Sebastian Münster (14881552). ${ }^{34}$ Finally, a Lapide frequently cites Desiderius Erasmus (1466-1536) and his edition of the New Testament, usually to compare his translation to that of the Vulgate. He views it neither with automatic disdain or with automatic approval, but judges it only on the merits of the translation with regard to the original Greek and the context of the passage..$^{35}$ In addition to the grammars of Bellarmine, van Ravelingen, Pagnino, and Rabbi David Ben Yosef Qimhi (11601235), a Lapide's commentaries also mention Jewish authors like Solomon ben Isaac (1040-1105), Saadia ben Yosef (882-942), and Ben Meyr De Balmes $(1460-1520) \cdot{ }^{36}$

It is likely that a Lapide was further formed in Hebrew studies by contact with the Hebrew professors of the Collegium Trilingue during his time at Leuven. ${ }^{37}$ The earliest Hebrew grammar produced at Leuven was that of Johannes Campensis (or Jan van Campen, 1490-1538), a professor from 1520 to 1531. In 1528, he published Ex variis libellis Eliae [...] huc fere congestum est opera Johannis Campensis: Quidquid ad absolutam grammaticen Hebraicam est necessari$u m .{ }^{38}$ At the Trilingue, van Campen worked primarily on the book of Psalms, but his Hebrew grammar likely remained influential at Leuven and may have

32 A Lapide, The Great Commentary, trans. Cobb, 8:269.

33 For a few of a Lapide's references to Vatable, see his comments on Mt 6:5; 11:23; 23:35; 26:12; Mk 7:4; Lk 3:15; 4:17; 10:18; 11:41; 12:29; 24:41; Jn 1:5; 1 John 3:1; 4:18; 5:20; 3 John 9; 1 Cor 5:8; 9:5; 11:20; 13:4; 14:21; 2Cor 1:8; 2:10; 5:8; 8:15; 9:10; 10:12; 12:17; 13:11; Gal 1:4; 2:17; 3:19; 5:1; 6:1.

34 See, for example, a Lapide's comments on Deut 27:8 where he cites Levita. See a Lapide, Commentaria in Pentateuchum Mosis (Antwerp: Martin Nutius and John Meursius, 1616), 1028.

35 For a Lapide's references to Erasmus, see his comments on Mt 2:11; 16:18; 19:6; Lk 1:26; 2:22; 16:8; Jn 1:1; 1 John 1:2; 5:20; 3 Jn 9; 1 Cor 1:13; 7:1; 8:10; 9:27; 10:13; 11:2; 12:6; 13:2; 14:14; 16:22; 2 Cor 3:18; 4:1; 5:8; 6:4; 7:3; 8:9; 9:5; 10:5; 12:7; Gal 1:4; 2:11; 3:1; 4:3; 5:1; 6:1.

36 See, for example, van Ravelingen's introduction to his Grammatica Hebraea and a Lapide's interpretation of 1 Cor 14:21, as well as his comments on Exodus 28:39 where he cites them. See van Ravelingen, Grammatica Hebraea, 1; a Lapide, The Great Commentary, trans. Cobb, 7:354; a Lapide, Commentaria in Pentateuchum Mosis, $55^{2}$.

37 On the early history of the Trilingue, see Henry Vocht, History of the Foundation and the Rise of the Collegium Trilingue Lovaniense, 1517-1550 (Louvain: Bibliothèque de l'Université Bureaux du Recueil, 1951).

38 Jan van Campen, Ex variis libellis Eliae, grammaticorum omnium doctissimi, huc fere congestum est opera Johannis Campensis, quicquid ad absolute gramaticen Hebraicam est necessarium, etc. (Louvain: Dirk Martens, 1528). 
been around during a Lapide's time there. ${ }^{39}$ When van Campen's tenure as professor of Hebrew at the Collegium Trilingue came to an end, he was followed in turn by Andreas van Gennep (1532-68), Johan Willemsz (1538-78), and Petrus Pierius a Smenga (1612-55). While van Gennep published a Hebrew grammar in 1564 (reprinted in 1570), Johan Willemsz appears to have published only biblical indexes for the Antwerp Polyglot Bible; Smenga does not appear to have published any biblical works during his tenure. ${ }^{40}$ Finally, it is likely that a Lapide was aware of the work of Isaac Johann Levita (1515-77), another active figure in Leuven who collaborated with Plantin and van Gennep, as well as Nicolas Cleynaerts's (1495-1542) work Tabula in grammaticen Hebraeam. First published in 1529 at Leuven, the work was exceedingly popular and republished twenty-three times throughout Europe, up until 1589 when it was published in Leiden. ${ }^{41}$

Turning to a Lapide's statements regarding the Hebrew language, I have collected nearly every example of a Lapide making a statement on the nature of the Hebrew language in order to provide a glimpse into Catholic Hebrew studies at the time. ${ }^{42}$ I have organized them into twelve thematic groupings, which cover, among other topics, the origin and history of the Hebrew language, its grammatical features, and the nature of Hebrew literature.

\section{The Origin and History of the Hebrew Language}

A Lapide first discusses the history of the Hebrew language in his commentary on the book of Genesis. In it, he follows the common belief of his time that Hebrew was the world's first language. ${ }^{43}$ However, he does recognize that it has

39 See for example: van Campen, Psalmorum omnium iuxta Hebraicum veritatem paraphrastica interpretatio (Nuremberg: Petreius, 1532); Campensis, Enchiridion psalmorum (Lyon: Seb. Gryphius, 1533); Campensis, Ioannis Campensis paraphrastica interpretatio in Psalmos omnes et Ecclesiasten (Cologne: John Gymnicus, 1534); van Campen, Den psalter des coninclijcken propheet Davids (Leiden: Peter Claessoon van Balen, 1537) van Campen, Psalmorum Davidis paraphrasis (Basil: Nicolas Episcopius Iunior, 1553).

40 Andreas van Gennep, Grammatica Hebraea (Antwerp: Plantin, 1564); Johan Willemsz, Index biblicus (Antwerp: Plantin, 1571).

41 For the numerous editions of Cleynaerts's work see Jalón and Díaz, "Repertorio de gramáticas hebreas," $578-83$.

42 Although I have tried to make this an exhaustive list, space constraints have forced me to choose the most pertinent examples of a Lapide's comments on Hebrew, those that best reflect the breadth of his knowledge and his genuine interest in the language. I am particularly grateful to Dr. Gregory Vall for his initial help in reviewing a Lapide's remarks. 
been influenced by other languages, ${ }^{44}$ has evolved over time, ${ }^{45}$ that it underwent a significant evolution during the Israelites' captivity in Babylon, ${ }^{46}$ and that the Hebrews spoke a "semi-Chaldean" or "Hebrew-Syriac" dialect until the time of Christ. ${ }^{47}$ In regard to the actual script, he believes that the letters of the Hebrew script were invented by Ezra-a common early modern misconception. ${ }^{48} \mathrm{~A}$ Lapide also apparently thought that there was a system of punctuation that began around the time of Jerome. ${ }^{49}$ Here, he may be thinking of the naqdanim who first supplied vowel points, dageshes, and accents, but they lived in the seventh century $\mathrm{CE}$, considerably later than Jerome. ${ }^{50}$ Finally, a Lapide held such a high view of Hebrew that he mused that it would likely be the common tongue of the blessed in heaven. ${ }^{51}$

\section{Hebrew Nouns: Gender, Generality, and Abstraction}

In addition to recognizing some of the basic traits of Hebrew orthography, ${ }^{52}$ a Lapide discusses Hebrew nouns in a number of places, as well as biblical Hebrew's understanding of gender, generality and abstraction. For example, he says that "they [the Hebrews] use the feminine gender for the neuter, which they lack,"53 and that when they desire to signify something general, "they combine the feminine with the masculine gender." ${ }^{4}$ In a similar vein,

44 CSS, 1:176; 21:328.

45 CSS, 14:309.

$46 \quad$ CSS, $4: 202,214,248 ; 10: 572 ; 12: 3$.

$47 \quad$ CSS, $17: 69 ; 19: 348$.

48 CSS, 4:20. There is now paleographic evidence to reconstruct the long, slow development of various scripts over the course of the biblical period. See Bruce Waltke and Michael O'Conner, An Introduction to Biblical Hebrew Syntax (Winona Lake, IN: Eisenbrauns, 1990), 1.5; Wilhelm Gesenius, Gesenius' Hebrew Grammar, ed. Emil Kautzsch, trans. Arthur Ernest Cowley (Mineola, NY: Dover Publications, 2006), 2a-2w.

49 CSs, 19:481.

$5^{\circ} \quad$ Waltke and O'Connor, Hebrew Syntax, 1.6.

$51 \quad$ CSS, 14:304; 21:328.

52 A Lapide was aware of the obvious distinctive qualities of Hebrew, such as that its silent letters often change with the addition of suffixes and prefixes (css, 13:106); it only uses consonants in its words (CSs, 13:173); it often doubles its root letters (css, 20:401); and that it has words/letters that can look the same but have different meanings, such as keri and ketif(css, 20:206).

53 CSS, 12:129; 14:403.

54 CSs, 11:79, 481. According to Waltke and O'Connor, there are several distinct (though perhaps related) phenomena that a Lapide may have in mind when he states that "Hebrew uses the feminine for a neuter": (1) the use of feminine pronouns when there is no clear antecedent ("Because you have done this thing [zot]" in Gen 3:14), (2) the use of feminine 
he states that Hebrew often doubles a word as a sign of comprehensiveness. Citing Isaiah 3:1 (and other places), he says that the Hebrew text combines a masculine and a feminine participle, which he then translates into Latin as "a masculine supporter" and "a feminine supporter" (sustentantem et sustentatricem), explaining that this means that every type of support will be withdrawn from Jerusalem. ${ }^{55}$ Finally, a Lapide held that they chose abstract names or terms to refer to concrete realities, ${ }^{56}$ something which does occur in Hebrew poetry.

\section{Hebrew Indicators of Syntax}

In a Lapide's discussion of Hebrew syntax, one is reminded that he was not writing a grammar when he makes comments on the language. Rather, he is only making quick remarks in the course of his biblical commentaries, to students trained primarily in Latin. For this reason, his short statements such as the "Hebrew language lacks cases," 57 that "they can use the same form to signify every case,"58 or that "names can be adapted into any case," simplistic. Nevertheless, rather than dismissing him, one can generally see his point by undertaking a further study of the passage he is commentating on. ${ }^{60}$

plural forms of the adjective for "things" of a certain quality (qashot, "harsh things" in Gen 42:7), and (3) feminine abstract nouns, see Waltke and O'Connor, Hebrew Syntax, 6.4.2b. On this issue, see also Paul Joüon and Takamitsu Muraoka, A Grammar of Biblical Hebrew, 2 vols. (Rome: Pontifical Biblical Institute Press, 1993), 134 e.

55 CSS, 12:370.

$56 \quad$ CSS, 9:114; 10:203; 11:77, 511; 21:207. E.g., "Your men will fall by the sword, and your might [= mighty ones] in battle" (Is 3:25). Cf. Joel LeMon and Brent Strawn, "Parallelism," in Dictionary of the Old Testament: Wisdom, Poetry and Writings, ed. Tremper Longman and Peter Enns (Downers Grove: Inter-Varsity Press, 2008), 502-15; Ernest Lucas, "Terminology of Poetics," in Dictionary of the Old Testament, $5^{20-25}$.

57 Css, 6:64, 68, 145, 153, 466; 8:18; 9:554, 659; 13:393, 1; 20:637.

$5^{8} \quad$ CSS, 11:301, 422.

59 CSs, 5:292, 427. With regard to the adaptability of Hebrew names, a Lapide is referring to the fact that Hebrew names were generally transliterated into Latin as indeclinable nouns and so without the addition of Latin case endings. By contrast, Hebrew names transliterated into Greek (LXX, NT) sometimes picked up Greek case endings (especially the nominative and accusative).

6o While a Lapide is correct in recognizing Hebrew's lack of cases in the biblical text, Hebrew did have at one point a working system of case endings, see Joüon And Muraoka, Grammar of Biblical Hebrew, 93b. In fact, vestiges of this case system survive in biblical Hebrew, especially in poetry that tends to preserve archaic and archaistic elements, see Joüon and Muraoka, Grammar of Biblical Hebrew, 93g-s. His statement that Hebrew uses the "same case" for everything is essentially true. However, the absence of case endings 
His reference to enallage, or the substitution of one word with another in a different grammatical form, reveals his awareness of the fluid nature of Hebrew syntax. For example, in Hebrew poetry (and even sometimes in prose) we occasionally find a qatal verbal form where we would have expected a yiqtol verbal form or vice versa. Furthermore, a Lapide states that "they understand the use of the function of the genitive like the nominative,"61 "they express the use of the genitive through a quasi-ablative construction using the preposition, ${ }^{62}$ and that "the Hebrews may repeat a term in a genitive construction to signify something special."63

\section{Hebrew Numbers}

In regard to Hebrew numbers, a Lapide correctly notices that the Hebrew language often uses cardinal numbers rather than ordinal numbers. ${ }^{64}$ The most famous example is the "one day" in Gen 1:5 (as well as in 2:11) which Augustine emphasizes since it supports his idea that creation was really "one day." In addition, a Lapide also recognizes that feminine forms are used for masculine and vice versa in the cardinals $3^{-10}$. This is likely what a Lapide is referring to when he says that they engage in an "enallage of numbers." ${ }^{65}$ Concerning the numbers of a group, he displays a slight skepticism in regard to the large numbers given in scripture. According to a Lapide, rather than counting each and every individual, the Hebrews chose to estimate using a definite number rather than giving a general estimation with an indefinite number. ${ }^{66}$ Finally, a Lapide remarks that the numbers seven and ten occur frequently in the Hebrew scriptures and carry extra significance. ${ }^{67}$

does not mean that biblical Hebrew is entirely bereft of indicators of syntactic function. For example, Hebrew has an accusative marker (et), and Hebrew nouns have a form called the construct form which is a form used for making quasi-compound nouns. See Waltke and O'Connor, Hebrew Syntax, 4.6.2, 8.2, 9.1a.

61 CSs, 5:495.

62 CSS, 10:209; 13:128; 13:167.

63 Css, 14:83. In this last phrase, a Lapide is thinking of expressions such as "heaven of heavens," "holy of holies," and "king of kings."

64 css, $5: 166 ; 13: 537$.

65 CSS, 10:42.

66 A Lapide remarks that the Hebrews proclaim the number of the whole by listing its parts, putting lesser numbers before greater ones (css, 13:126), and also that when they wish to estimate a group, they "use a definite number instead of an indefinite one" (css, 15:27).

$67 \quad$ Css, 12:126. 


\section{Concerning Pronouns}

A Lapide has some interesting remarks regarding pronouns that show a close reading of the Hebrew text. For example, he points out that "the absolute and reciprocal pronoun are the same in the Hebrew language" 68 and can "connect the demonstrative pronoun to the antecedent substantive."69 He rightly recognizes that the same pronominal form may refer either back to an antecedent actor or to a third party. For example, "Ehud made for him $[l o]$ a sword" (Jdg 3:16) is understood in context to mean that he made a sword for himself, although in a different context the very same words could mean that he made a sword for someone else. ${ }^{70} \mathrm{~A}$ Lapide is also aware of the importance of context in the Hebrew language, pointing out that relative and demonstrative pronouns are often not specified, such as we find in Gen 3:14: "What is this you have done?"71 Finally, he makes the interesting observation that "they often understand the relative pronoun "who" [qui] as implied."72 In this case, he may be referring to the famous resumptive or specifying pronoun, which is highly characteristic of biblical Hebrew: "I am Joseph your brother, 'asher you sold me into Egypt," instead of "I am Joseph your brother, whom you sold into Egypt."73

\section{Concerning Hebrew Words in General}

In discussing Hebrew words in general, a Lapide frequently talks about "active Hebrew words." For example, he says that active Hebrew words "often do not signify action but the evidence of action,"74 that they "often signify a desire or permission to act," 75 that they frequently "do not signify an action or an effect, but the power, strength, or ability to act,"76 and that they cannot signify its completion, but only the beginning of acting, such as a proposal, purpose, or effort of an action. ${ }^{77}$ In this regard, it appears that a Lapide is thinking of non-stative verbs, akin to what Waltke and O'Connor describe as "fientive

\footnotetext{
68 CSs, 6:394; 9:62, 685; 15:113.

69 Css, 9:145.

70 In such an instance the pronominal suffix is said to have "reflexive force." See Joüon and Muraoka, Grammar of Biblical Hebrew, 146k; Waltke and O'Connor, Hebrew Syntax, 6.4g.

71 CSS, 15:26; 11:79; 15:281.

72 CSs, 9:659; 10:430.

73 Waltke and O'Connor, Hebrew Syntax, 19.3b.

74 Css, 17:282.

75 Css, $18: 26$.

76 Css, 13:243.

77 CSS, 3:104; 11:636; 13:251; 15:25, 362; 18:28.
} 
verbs." ${ }^{78}$ A Lapide also makes numerous references to Hebrew adverbs and shows that he was aware of biblical Hebrew's ability to express adverbial notions in ways that were different from Latin. ${ }^{79}$ In addition, he also states that the Hebrews expressed a vehemence of an action by doubling a word, "as if it were a superlative," 80 and that they used "real words" in the place of mental or abstract ideas, and that these can be used "with an ablative construction with the preposition bet, ${ }^{81}$ and that they may use it "with an ablative or accusative sense." 82 Finally, a Lapide remarks that "imperfect words often change their order" referring to the tendency of weak verbs to lose letters with the addition of prefixes and suffixes. ${ }^{83}$

\section{The Syntax of Hebrew Verbs}

A Lapide discusses verbs at numerous points, only a few will be included here. In general, a Lapide is aware of the complexity of Hebrew verbs. ${ }^{84}$ However, he still views them in terms of Latin grammar and so he constantly remarks on the enallage of Hebrew verbs in regard to person and number. ${ }^{85}$ For example, he finds all other uses of the "future" or "preterite" that do not line up with the (Latin) tenses he has assigned them to be instances of enallage. He comments on the broad use of Hebrew infinitives, recognizing that infinitives (construct or absolute) are not marked for mood or tense. ${ }^{86}$ Furthermore, he states that the Hebrew authors "may use the imperative for the future when they desire to signify its certitude," 87 that they "use the infinitive for the future tense" 88 and

78 Waltke and O'Connor, Hebrew Syntax, 22.2.1a-22.2.3c.

79 Css, 13:352; 16: 263. Biblical Hebrew often uses prepositional phrases adverbially, see Joüon and Muraoka, Grammar of Biblical Hebrew, 102; Waltke and O'Connor, Hebrew Syn$\operatorname{tax}, 4.2 .2 ; 4.4 .1 ; 4.5$ c; 4.6.1-2; 39.3-5.

8o A Lapide is here referring to the priestly miod miod.

81 A Lapide is thinking of verbs that take their object with the preposition bet e.g., bahar, CSS, 5:223, 9:56; 10:117; 18:29; 21:256, 326 .

$82 \quad$ CSS, $5: 559 ; 9: 613 ; 10: 133-4,285,387,432,495 ; 14: 205,275 ; 15: 274 ; 18: 29 ; 20: 363,456$

83 CSs, 13:418, 487; 14:483. See Joüon and Muraoka, Grammar of Biblical Hebrew, 71.

84 The fluid nature of the Hebrew verbs is well known. Waltke and O'Connor even state that "patience is needed for work on the Hebrew conjugations." Waltke and O'Connor, Hebrew Syntax, 29.6a, 34. See also Joüon and Muraoka, Grammar of Biblical Hebrew, 113a-o.

85 For example, he states that "enallage of number" occurs frequently in Hebrew verbs, see CSS, 14:225, 410. For "enallage of person" see 5:409, 482; 10:454; 11:370; 12:208; 14:193, 301, 512; 20:319. Furthermore, he also says that "they often shift between past, present and future tenses" (Css, 11:70).

86 Css, 5:466; 18:26.

$87 \quad$ CSs, $6: 60 ; 13: 420 ; 15: 264$.

88 Css, 12:629. 
for the "preterit tense." 89 For the yiqtol form, a Lapide appears to recognize that it is essentially aspectual and can be used as a future, as a present (ongoing, iterative, or habitual), or even a past tense (ongoing, iterative, or habitual). ${ }^{90}$ He affirms that the "future tense" can have the force of an imperative, clearly meaning what we would label as the jussive form..${ }^{91}$ Concerning Hebrew particles, he says that "they often use participles for verbs that express anger,"92 and that "they use participles for the indicative [present] tense, which they lack." 93 A Lapide refers to the infinitive construct as a gerund, saying that it can have either an active or passive tense. ${ }^{94}$ For example, a suffixed infinitive construct qotlo can refer to "his killing [someone]" or "his being killed." With regard to the qatal, a Lapide refers to as "the preterit." ${ }^{25} \mathrm{He}$ does, however, recognize the frequent use of the waw conjunction, but he does not articulate the difference between the wayyiqtol form and the circumstantial waw. ${ }^{96}$

89 CSs, 13:358. This is true if a Lapide is referring to the infinitive absolute, but not if he has the infinitive construct in mind, see Waltke and O'Connor, Hebrew Syntax, 35-36.

9o For more on the yiqtol form, see Joüon and Muraoka, Grammar of Biblical Hebrew, 113; Waltke and O'Connor, Hebrew Syntax, 20.

91 CSS, 5:74; 20:24. A Lapide also remarks that "they express the optative mood which they lack, through the future tense" $(7: 466 ; 20: 24)$ and that "they can use the future tense in the place of participles" (14:83). Furthermore, he says that "they often use a future instead of an indicative [present] sense" (14:300) and that "through a future they may express the constancy, continuation, or habit of some thing" (14:187, 309; 21:17). According to Jouon, the yiqtol can express what he calls the "modal nuances" (pouvoir, devoir, vouloir). Often the second person yiqtol expresses what one must or must not do ("thou shalt"). In addition, the "converted perfect" in a chain of instructions has a quasi-imperatival force.

92 CSS, 20:245.

93 Css, 9:659; 10:430. A Lapide appears to be thinking of the present tense when he mentions the "indicative." If so, he may be mistaken since in classical biblical Hebrew, the participle was unmarked for tense (it was not a present tense) and only sometimes expresses an ongoing aspect. Already in late biblical Hebrew, and more and more decisively in postbiblical Hebrew, it comes to be used to express present time and ongoing aspect. Finally, in modern Hebrew the participle has come to serve as the present tense. But this usage must not be read back into classical Hebrew. On the danger of modernizing or archaizing the Hebrew Bible, see Waltke and O'Connor, Hebrew Syntax, 1.4.1.

94 CSs, 18:27. See Waltke and O'Connor, Hebrew Syntax, 36.2.3e-36.3.2

95 Css, 5:104. The true preterit of biblical Hebrew is wayyigtol, often labeled as the "narrative tense" or the "converted imperfect." See Joüon and Muraoka, Grammar of Biblical Hebrew, 112.

96 For example he says that "since the Hebrew language appears to lack a present tense, they can express the present through the preterit" (CSs, 14:595), and that "through the preterit, they may understand either the present or the future, or vice versa" (21:281). 


\section{Hebrew Particles and Prepositions}

Discussing Hebrew particles and prepositions, a Lapide primarily refers to the wide variety of uses for the preposition bet. For example, he says that it can be used to signify "through," "with," "near," "among," and "on account of." 97 He also says that it "can signify merit or demerit,"98 can be used "to govern a case,"99 to "signify value"100 and "instrumental causality."101 A Lapide also mentions the conjunction כ $[k a f]$ recognizing that "they often begin paragraphs with the conjunction"102 and "that they often explain the previous sentence with the preposition כ כ $[k i]$."103

\section{Hebrew Adjectives}

For adjectives, while a Lapide does recognize that Hebrew expresses comparisons differently from Indo-European languages, he also slips back into describing Hebrew according to Latin grammar. Thus, he says that "the Hebrews lack grades of comparison,"104 but then in another place, he explains how they use the preposition מ $[\mathrm{min}]$ to expressive comparative grades. ${ }^{105}$ In addition, a Lapide notices that a Hebrew adjective, while usually agreeing with the most proximate substantive, can also refer to one more remote. ${ }^{106}$ Finally, he mentions that "they express the greatest and most excellent things in the plural," referring to "Elohim [God] and the cognate construct chain "holy of holies."107

\footnotetext{
97 CSS, 11:72; 10:353; 20:97.

$98 \quad$ Css, 13:354.

99 CSs, 15:671. For an "accusative case," see css, 5:687, and for a "genitive case" css, 12:128. In the context, he merely means that the particle governs the function of certain words, since he has elsewhere been very clear that Hebrew has no cases. When he says that the preposition in may be used for an accusative case, he may have in mind the way that certain verbs (like bahar: "to choose") require their objects to be governed by the preposition bet, but this is not a true accusative usage. Generally, however, the preposition is much more commonly used in true prepositional phrases. See Waltke and O'Connor, Hebrew Syntax, 11.4; Joüon and Muraoka, Grammar of Biblical Hebrew, 132.

$100 \quad$ CSS, 13:453.

101 CSS, 11:72; 15:104; 18:676; 21:257.

102 CSS, 11:121.

103 CSS, 14:121.

104 CSS, 9:522.

105 Css, 16:244. He also says that though the "lack comparatives, they express what is less through negation" (5:207; 9:371; 15:27).

106 CSs, 20:475; 21:350. Waltke and O'Connor do not touch upon this application of Hebrew adjectives and Joüon mentions only one "possible" case in Gen 4:10.

107 CSS, 14:117.
} 


\section{Hebrew Comparisons}

When discussing Hebrew comparisons, a Lapide affirms that the "Hebrews rejoiced in comparisons, in stories, and in metaphors." 108 However, he does have a habit of taking a single instance of Hebrew usage and presenting it as a general norm. ${ }^{109}$ One should keep in mind, however, that a Lapide is not trying to provide a complete or systematic Hebrew grammar, but only to aid his readers in understanding a particular passage of scripture. To mention a few of his more interesting claims, he sustains that arguments between people may be described as "bones" and refers to Is 41:21, where the word has the same root consonants as "bone" and apparently means "arguments," either "strong arguments," or "defensive arguments," depending on the original etymology (Ugaritic/Phoenician or Arabic). A Lapide also thought that there was an etymological connection between ben [son] and beth [house], even though we now know this not to be the case. He also states that the term for "stomach," i.e., qrb, [literally "middle" or "midst"] can refer to the abdominal area, a legitimate, if somewhat rare meaning. Finally, a Lapide expresses a slight skepticism in reading Hebrew literature holding that "they often personify and ascribe animation to inanimate things"110 and "they call every circumstance, disposition of nature, and future event, as a command of God."111

\section{Hebrew Literature, Poetry, and other Idioms}

To conclude this section, we should note a few, final remarks from a Lapide on Hebrew literature, poetry, and other idioms. Of literature, he states that the Hebrews focused their study/writings on sacred scripture and "little is known about other Hebrew writings." 112 He identifies some salient features of Hebrew prose, including its characteristic use of parallelism ${ }^{113}$ and the general

\footnotetext{
108 CSs, 5:74; 9:26; 18:269.

109 To mention only a few, he gives the following examples of individual comparisons as general statements regarding the Hebrew language: "They call every piece of land dust" (css, 14:211), "they call the sun and stars 'the army of God," (9:471), "they call cities 'vineyards' and citizens 'vines," (12:304), "they are accustomed to call cities 'young women' on account of their beauty, glory, and influence" (13:578), and "through 'honey' they designate all sweet things" (11:202).

110 CSS, 11:464; 14:241.

111 CSS, 14:38.

112 CSS, 18:253.

113 "In their songs and poetry, the Hebrews are accustomed to repeat what was said in the previous stanza, as if to say the same thing twice" (CSs, 5:24, 32, 53, 136, 205; 13:551).
} 
difficulty of its syntax. ${ }^{114}$ Finally, there are a few random statements that are worth mentioning. These include a Lapide's awareness of "a great variety in Hebrew codices,"115 and a few remarks on Hebrew idiomatic expressions, such as "they [the Hebrews] confirm a statement by denying the contrary,"116 "when they desire to accuse someone, they do it by interrogating them,"117 and "when they desire to assert something, they double their positive assertion, but triple their negative assertion." 118

Reflecting on these statements, a Lapide has clearly paid close attention to the Hebrew text. The view that Catholic scholars merely retreated into the Vulgate after Trent should be questioned. One also notices the influence of the King's Bible (Antwerp Polyglot) and Pagnino's grammar in a Lapide's discussion of Hebrew. In his general approach to Hebrew, a Lapide appears to follow the mold set by the Polyglot and Bellarmine's grammar. For example, Bellarmine's grammar is divided into parts: the first on reading and writing Hebrew, the second on nouns, the third on verbs, and the last on de reliquis partibus grammaticae, including syntax and poetry, a formulation that a Lapide has clearly followed. ${ }^{119}$ The influence of Bellarmine's grammar also reveals that a Lapide was aware of the Hebrew grammars of Rabbi Qimhi, Rabbi Eliah Levita (14691549), and Pagnino. Bellarmine cites all three when he disagrees with Levita's view that there are only seven conjugations of Hebrew verbs. Bellarmine says that although most recent commentators follow Rabbi Levita in positing seven (Qal, Niphal, Piel, Pual, Hiphil, Hophal, and Hithpail), he prefers the view of Pagnino and Qimhi, who see an eighth, adding the conjugation Poel. ${ }^{120}$ Thus, while a Lapide appears to rely heavily on Bellarmine and the Polyglot, a deeper analysis reveals the broad array of sources used by Jesuits in the late sixteenth and early seventeenth centuries in their study of Hebrew. In particular, the influence of Jewish works in the formation of Jesuit Hebrew studies should not be underestimated.

\footnotetext{
114 "They speak very concisely in their songs and poetry, leaving many things out that have to be inferred from the context" (css, 13:489).

115 css, 6:311.

116 CSS, 20:559.

117 CSs, 20:341.

118 CSs, 16:315.

119 This appears to be a fairly common layout for Hebrew commentaries at the time.

120 Bellarmine, Institutiones linguae Hebraicae, 59. Rabbi Levita apparently argued that the poel was simply a rare form of the piel conjugation. Bellarmine argued that it should have its own form. Raphelengius's grammar lists it as a version of the pual form, calling it the poel quadrata. See van Ravelingen, Grammatica Hebraea, 3.
} 


\section{Conclusion}

Returning to our original question posed by Gibert, how is a Lapide a "sort of transition" in the history of biblical exegesis? A Lapide is a sort of transition in that he attempts to combine the ancient and medieval approaches to scripture with the emerging humanistic and historical studies of the early modern period. He approaches scripture first and foremost as the word of God that cannot err (when properly interpreted) and views the doctrines and dogmas of the church as guides for one's interpretation and not as obstacles. Unlike later exegetes such as Baruch Spinoza (1632-77) or Hermann Reimarus (1694-1768), if there appears to be a discrepancy or contradiction in scripture, a Lapide remains confident that God has preserved the scriptures and the church from all error. On the other hand, a Lapide extensively studied the writings of his contemporaries and was firmly convinced of the importance of doing a solid historical and philological study of scripture. Though he lists the most prominent interpretative positions of the tradition, he does not follow them blindly, but compares them to the findings of contemporary scholarship and judges everything according to what makes the passage most intelligible or coherent in its own context. Despite his affirmation of the Vulgate as "authentic" scripture, he believed that the original texts "shed light" on the Vulgate by providing access to the "genuine sense" of God's revelation and therefore provided a "fuller" or "deeper" understanding of divine truth. Grounding his exegesis on the literal sense, a Lapide proposed guidelines for reigning in excessive spiritual interpretations by stressing their correlation with the literal. While his knowledge of Hebrew was a product of his times, he clearly sought to have the most upto-date material available and to familiarize himself with every major Catholic and Jewish commentator of scripture. His comments on the Hebrew language reveal a close reading of the text and a deep appreciation for the language. In the history of Catholic Hebrew studies, although he did attain considerable skill in Hebrew, a Lapide's lasting contribution to the field is his example of incorporating philological and historical studies into discussions of church doctrine and patristic sources. By showing the possibility and fruitfulness of such an approach, a Lapide stimulated the incorporation of humanistic studies into Catholic biblical studies that was to benefit subsequent scholars. 